\title{
Influence of the vadose zone on groundwater pollution A review
}

\author{
Banajarani Panda a, S. Chidambaram b* \\ a Department of Earth Sciences, Annamalai University, Tamilnadu, India 608002. \\ b Research Scientist, Water Research Centre, Kuwait Institute for Scientific Research, Safat, Kuwait.
}

*Corresponding Author sabarathinam.chidambaram@, gmail.com

(S. Chidambaram)

Received : 26 03 2019

Accepted : 05 05 2019

\begin{abstract}
The vadose zone is the geologic profile that lies between the water table and the ground surface. It has low water content relative to the saturated zone and commonly referred as the unsaturated zone. Recharge to the water table passes through the vadose zone and understanding transport through this region is critical in groundwater pollution studies. Groundwater pollution is controlled by a number of physical and chemical processes which may retard or transform contaminants as they pass through the vadose zone. Porous materials hold water under tension as a component of soil structure, ambient fluid pressures and other factors. When vadose zone water content is below saturation, leakage liquid as well as the dissolved materials passed on in it are retained. Hydrologically, the depth of unsaturated zone plays an important role in controlling water movement and contaminant transport from the land surface to the aquifer. The purpose of this study is to present an overview of the principles of fluid flow and moisture retention in the vadose zone and its influence on groundwater pollution. The study is presented in two parts: Part I includes descriptions of zones of soil moisture, basic principles of properties controlling the fluid distribution in pore spaces and how subsurface soil properties can be used to assess the leachate mobility. Part II review the principle of fluid movement in the vadose zone and impact of seepage on groundwater pollution. This study will focus on how vadose zone conditions and soil properties act to control groundwater pollution.
\end{abstract}

Keywords: Groundwater pollution, vadose zone, unsaturated zone, contaminant transport.

\section{Introduction}

The vadose zone is the portion of the subsurface above the groundwater table. The vadose zone is further subdivided into three zones, i.e., soil water zone, intermediate zone and capillary zone [1]. The soil water zone is adjacent to the ground surface. The intermediate zone is between the lower edge of the soil water zone and the upper edge of the capillary zone. The capillary zone extends from the bottom edge of the intermediate zone to the upper edge of the saturated zone [1]. As shown in Fig 1, the vadose zone includes surface soil, unsaturated subsurface materials (partially weathered soils and un weathered parent material) and a transiently inundated capillary fringe/zone [2]. The vadose zone has low water content relative to the saturated zone below the water table and is therefore commonly referred to as the unsaturated zone. Above the capillary zone, vadose zone pore spaces are generally air filled, with thin water films coating solid particles. Pore spaces become water filled when rainfall percolates, followed by drainage and gradual drying. The vadose zone may be very shallow (less than $1 \mathrm{~m}$ ) or very deep (extending hundreds of meters or more), depending on the depth to the water table [2].

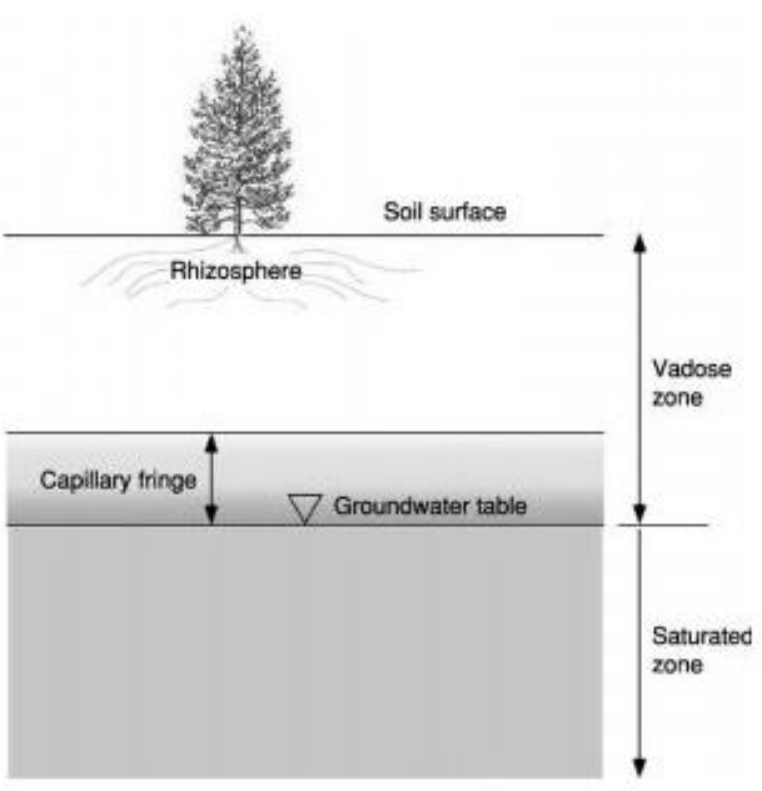

Fig 1. The vadose zone profile [2]

Deeper vadose zone substantially influences natural recharge of groundwater, as well as contaminant transport. Recharge water has to pass through the vadose zone to reach the water table below. As water will pass through this 
unsaturated zone, it can accumulate various contaminants in the process and pollute the groundwater below. Therefore, understanding the water flow processes through vadose zone is of utmost importance as it dictates the quality of groundwater. Thus, the main objective of the study is to review both hydrologic and hydrochemical information regarding vadose zone to estimate the total impact of seepage from unsaturated zone on groundwater resources and pollution.

\section{Natural filtration in vadose zone:}

Hydrologically, the unsaturated zone is often the main factor controlling water movement from the land surface to the aquifer [3]. It is often regarded as a filter that removes undesirable substances. The rates and direction of movement of contaminants, their fate along migration due to the chemical reactions is significant in the unsaturated zone [3]. Hence, the vadose zone is identified by several authors $[3,4]$ as a natural filter in adsorbing the contaminants in water before it reaches the water table. The study of the contaminants in the vadose zone cores will provide an idea on the type of adsorptions and its variation with depth. It will also pave way to identify the governing factors controlling these processes.

The time for contaminants from different fields like industrial effluent, irrigation field, domestic sewage etc. to reach water table increases with decreasing the particle size in vadose zone and water table depth (Bower et al. 1969). Due to nonuniform irrigation practices and preferential flow, some deep percolation water will reach the groundwater much faster [5,6]. Dissolved salts, nitrate, and pesticides are the chemicals in deep percolation water of main concern in groundwater pollution [6].

\section{Groundwater movement in vadose zone:}

Significant amount of rainfall during the monsoon and hence each large rain event initiates infiltration wave that propagates into the vadose zone and pushes the wetting front farther down. Groundwater recharge can be calculated from the variations in vadose zone water storage [7]. An increase in vadose zone water storage is attributed to an infiltration event, while a reduction in water storage is attributed to a draining process [7]. This is also evident from the measurement of water table in the phreatic aquifer.

\section{Anthropogenic influence in vadose zone:}

Spatial distribution of $\mathrm{NO}_{3}-\mathrm{N}$ in deep vadose zones is an indicative of transport of $\mathrm{NO}_{3}-\mathrm{N}$ between the root zone and the water table. Since, some of this added $\mathrm{NO}_{3}$ is leached below the root zone, the change from higher to lower concentrations of $\mathrm{NO}_{3}$ in soil water at depth is an indication of the position in the profile of recharge originating at the time of increased use of $\mathrm{NO}_{3}$. More specifically, nitrogen isotopes can be used to determine sources and pathways of migration of nitrates to natural waters [8]. The isotope studies on nitrogen used to be helpful in obtaining the relative contribution of fertilizer to the groundwater $[9,10]$.

Movement of pesticides may be retarded in the vadose zone, but biodegradation may also be slowed due to reduced organic carbon content and microbial activity at greater depths [11]. Because of the large area of irrigated land in the world and the real potential for groundwater pollution, more research is necessary on downward movement of water and chemicals in the vadose zone [6].

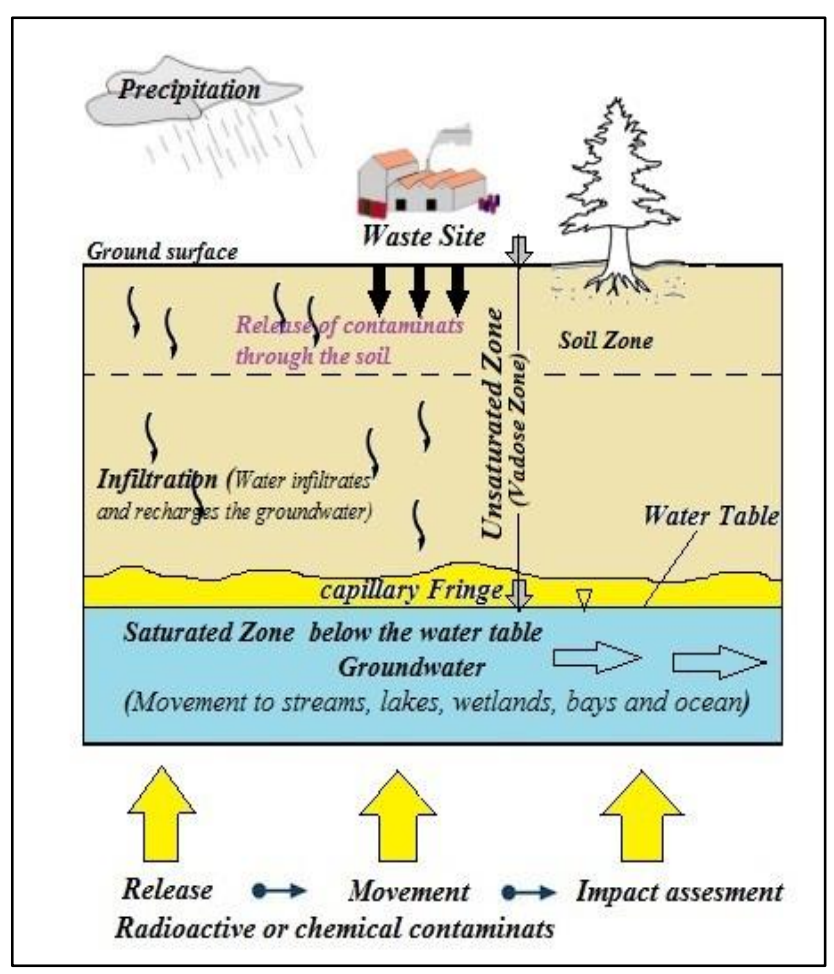

Fig 2. Schematic of fluid movement in the vadose zone.

There is always a variation in the physical and chemical processes in the vadose zone which is very efficient. For example. The concentration of contaminants is highest in the soil just below the earth' s surface. However, the pollutant concentration may vary as the degree of saturation is reduced. Therefore, conditions are favorable for adsorption and cation exchange on clay particles in the vadose zone. The low water content of unsaturated soil also reduces the mass of dissolved and mobile contaminants during reactions involving solubility limits. Porous materials retain water under tension as a function of soil structure, ambient fluid pressures and other factors. In this case, seepage liquid as well as the dissolved materials conveyed in it are retained in the soil. The retained leachate is temporarily 'or permanently prevented from percolating down to an aquifer. It is necessary to estimate the rate of seepage and the degree of saturation within the vadose zone as a first step in the evaluation of potential impacts of contaminated seepage. A schematic diagram (Fig 2) has been developed which shows the fluid movement and its influence on groundwater resources. 


\section{Vadose zone impact on groundwater pollution review}

This is the part II illustrating the influence of vadose zone on groundwater pollution.

The significance of vadose zone in wastewater reactions is evident after the success of millions of domestic and commercial septic systems [12 14]. Failure of such systems is often associated with submergence, overloading or other conditions which raise the degree of saturation [15]. Few of these studies are described below:

Martin [15] in his both the paper focused on seepage from surface facilities which pass through the vadose zone, (portion of the geologic profile above the water table) by describing the basic principles of moisture retention and the implications for leachate control. To illustrate these concepts, he derived 6 generalized examples in his first part which includes

\section{$>$ vadose zone storage}

$>$ land treatment of wastewater and sludges

$>$ waste dewatering

$>$ hydrocarbon spill storage

$>$ capillary break situations

$>$ air and water drainage under liners

The first part of the paper deals with the static conditions and companion paper deals with leachate flow and seepage in a wide range of applications in the vadose zone including.

$>$ steady vertical seepage

$>$ flow in the vadose zone parallel to a water table

$>$ development of groundwater mounds under liquid filled impoundments

$>$ wetting front advance through homogeneous soil

$>$ wetting front advance under lined impoundments

Bouwer [6] examined the depth of percolation water per season or per year, and the time the deep percolation water takes to reach the underlying groundwater, how fast it will join the groundwater where groundwater levels are changing, and what chemicals it may contain to understand the process and impact of vadose zone on groundwater resources. The effects of vadose zone on groundwater table fluctuations in unconfined aquifer has been studied by Kong et al. [12].

Evaluation of groundwater pollution and impact of vadose zone from an agricultural field using DRASTIC model and GIS has been studied by Ariffin et al. [13].

\section{Conclusion:}

This study has summarized the fluid movement along the vadose zone and also gives a detail understanding of subdivisions of groundwater regime. The study also reviews the status of the influence of vadose zone on groundwater resources.

Most of the studies on groundwater pollution have focused on contaminant transport in saturated aquifers. However, most of the cases, seepage from surface facilities must first pass through the vadose zone, which is that portion of the geologic profile above the water table. Generally, this zone is undersaturated which complicates the complicates the movement of leachate through soil because the permeability of the vadose zone varies with the degree of saturation.

Higher thickness of vadose zone impacts the groundwater recharge process as well as the pollutant transport because as described above the fluid has to pass through the vadose zone first to reach water table. As water will pass through this unsaturated zone, it can accumulate various contaminants in the process and pollute the groundwater below. However, it is often regarded as a filter that removes undesirable substances. Hence, flow in the vadose zone is an integral part of the fluid seepage and contaminant movement, and must be quantified for proper analysis and decision making.

\section{References}

1. O.E. Meinzer, Outline of ground water hydrology, US Geological Survey Water Supply Paper, 494 (1923) 5.

2. P.A. Holden and N. Fierer, Microbial processes in the vadose zone, Vadose. Zone. J., 4 (2005) 1 21.

3. J.R. Nimmo, Vadose water, Encyclopedia of Inland Water, 1 (2009) 766 777.

4. S Liu and T.C.J. Yeh, An integrative approach for monitoring water movement in the vadose zone, Vadose. Zone. J., 3 (2004) 681 692.

5. P.V. Roberts, P.L. McCarty, M. Reinhard and J. Schreiner, Organic Contamination Behavior During Groundwater Recharge, J. Water. Pollut. Control. Fed., 52 (1980) 161 172.

6. H. Bouwer, Effect of irrigated agriculture on groundwater, J. Irrig. Drain. Eng., 113 (1987) 4 15.

7. L.W. Dekker and C.J. Ritsema, How water moves in a water repellent sandy soil. 1. Potential and actual water repellency, Water Resour. Res., 30 (1994) 2507 2517.

8. C.W. Kreitler, Nitrogen isotope ratio studies of soils and groundwater nitrate from alluvial fan aquifers, J. Hydrol., 42 (1979) 147 170. 
9. C.W. Kreitler and L.A. Browning, Nitrogen isotope analysis of groundwater nitrate in carbonate aquifers: natural sources versus human pollution, $J$. Hydrol., 61 (1983) 285 301.

10. J.R. Gormly and R.F. Spalding, Sources and Concentrations of Nitrate-Nitrogen in Ground Water of the Central Platte Region, Nebraska, Groundw., 17 (1979) 291 301.

11. C.W. Kreitler and D.C. Jones, Natural Soil Nitrate: The Cause of the Nitrate Contamination of Ground Water in Runnels County, Texas, Groundw., 13 (1975) 53 61.

12. J. Kong, P. Xin, G.F. Hua, Z.Y. Luo, C.J. Shen, D. Chen and L. Li, Effects of vadose zone on groundwater table fluctuations in unconfined aquifers, J. Hydrol., 528 (2015) 397 407.

13. S.M. Ariffin, M.A.M. Zawawi and H.C. Man, Evaluation of groundwater pollution risk (GPR) from agricultural activities using DRASTIC model and GIS, IOP Conference Series: Earth and Environmental Science, 37 (2016) 012078(1 22).

14. J.P. Martin and R.M. Koerner, The influence of vadose zone conditions in groundwater pollution: Part I: Basic principles and static conditions, J. Hazard. Mater., 8 (1984) 349 366.

15. J.P. Martin and R.M. Koerner, The influence of vadose zone conditions in groundwater pollution: Part II: Fluid movement, J. Hazard. Mater., 9(1984), 181 207

\section{About The License}

(C) 2019 The Authors. This work is licensed under a Creative Commons Attribution 4.0 International License which permits unrestricted use, provided the original author and source are credited. 